\title{
Concerning the history of comparative psychology in Russia
}

\author{
I. A. Mironenko, V.A. Rafikova \\ St. Petersburg State University, \\ 7-9, Universitetskaya nab., St. Petersburg, 199034, Russian Federation
}

For citation: Mironenko I. A., Rafikova V.A. Concerning the history of comparative psychology in Russia. Vestnik of Saint Petersburg University. Psychology, 2020, vol. 10, issue 1, pp. 61-72. https://doi.org/10.21638/spbu16.2020.105

Psychology in the USSR was developing in relative isolation from international science. A substantial amount of research done by Soviet psychologists has remained unknown to the international scientific community, this especially concerns work performed since the 1930s. Scientists who worked during the first decades of Soviet rule had received their education in the pre-Soviet period. They knew foreign languages, and, for the most part, studied and completed internships in Europe, particularly in Germany. New generations that grew up under Soviet rule, in accordance with the Iron Curtain policy, were denied the opportunity to participate in international discourse. The development of Russian psychology in the war and post-war period led to the formation of a specific conceptual system, which is still a serious obstacle to the integration of the achievements of Russian science, since it requires not only language translation, but also hermeneutics. Nevertheless, there were original developments, mainly in the area of fundamental research connected with biological sciences, which still can contribute to international psychology. Such is the case with comparative psychology. This article dwells upon the history of research in comparative psychology in Russia; it expounds upon the specific character of the approach rooted in Russian science, and highlights the life and works of a number of prominent representatives of the Soviet school in comparative psychology (Ladygina-Kots, Fabri, Tikh) as well as research in the field executed by Pavlov.

Keywords: historical development of comparative psychology, evolutionary psychology, anthropogenesis, human phylogenesis and ontogenesis, Activity Theory, psychology in Russia.

It is well known that psychology in the USSR was developing in relative isolation from international science, a substantial amount of research executed by Soviet psychologists remains unknown to the international scientific community, particularly research executed by scientists who grew up and were educated during the Soviet period.

Russian scientists who born and educated before 1917 had a good command of foreign languages and were constantly communicating with foreign colleagues. Sergey Rubinstein, Nikolai Lange, Alexander Lazursky, Isac Shpilrein and others received their education and interned in Germany, France, and England as was typical for Russian intelligentsia before the October Revolution of 1917. These practices ended at the beginning of the 1930s. Soviet psychologists of younger generations were restrained with their language since the international dissemination of their results was restricted by the language barrier and severe administrative policies. Psychology in the USSR was, in forcible measure, kept within the framework of a mono-methodological trend, oriented to the standards of natu-

(c) Санкт-Петербургский государственный университет, 2020 
ral sciences and based on Marxist philosophy with a priority on fundamental research. Psychological practices were restricted, and the impact of ideology was a strong distorting factor for research in societal areas. Soviet psychology was in no way a comprehensively developed trend. However, on some issues, mainly in the area of fundamental research connected with biological sciences, there were original developments that still can make a contribution to international science, but they are not getting sufficient attention in the literature on the history of psychology in the USSR.

An example of this kind is Soviet comparative psychology, which was sustainably developing in the USSR; its theoretical and methodological basics were well grounded in the neurophysiology and physiology of sensory and motor processes, and it was closely connected to general psychology. Research was focused on the problem of human phylogenesis. This accounted for the specific character of methods used by Soviet researchers and their theoretical developments, which in significant aspects differ from Western approaches that are dominant in international science.

\section{Foundations of Russian Comparative Psychology}

The Russian tradition in comparative psychology, built on a solid foundation of internationally acknowledged Russian neurophysiology of the XIX century, was primarily interested with comparative analysis of the behavior of species viewed in the evolutionary perspective and in relation with the structure of the nervous system. Among those who contributed to investigations on the problem of evolution of mind and behavior was Ivan Sechenov (1829-1905), who established a tradition of considering the mind as primarily a function of the nervous system enabling motion of the organism. Sechenov used to say, the "Mind is born and dies with motion." Considering the development of mind in the evolutionary perspective, Sechenov was greatly interested in psychology. His works: "Psychological Studies" [1], "Who Must Investigate the Problems of Psychology, and How?" [2] and "Elements of thought" [3] had a major impact on the development of psychological science in Russia at the end of the $19^{\text {th }}$ century.

Another prominent neurophysiologist who contributed to the development of comparative psychology in Russia was Vladimir Bekhterev (1857-1927), world-famous neurologist and the founder of Russian objective experimental psychology, who founded the State Institute for Brain Research in St. Petersburg. His book "The Objective Psychology" [4] contains many comparative assessments of human and animal behavior. Bekhterev was interested in phylogenies of psychic functions in species, starting with protozoa. ${ }^{1}$

At the beginning of the $20^{\text {th }}$ century, a department of comparative psychology was operating at St. Petersburg Unversity, chaired by Vladimir Vagner (1849-1924). Vagner is acknowledged as the founder of the comparative psychology (biopsychology) school in Russia and developed the basics for this school. Biopsychology involved focusing on the evolution of psychic abilities of animals and humans in relation to general evolutionary processes [5]. Vagner traced the evolution of psychic abilities from single-celled animals to humans [6]. He argued that the human mind is a continuation of the development of psychic functions of animals on a qualitatively new level.

${ }^{1}$ Ladygina-Kots, a well-known researcher in comparative psychology, recalled that her interest in animal behavior was inspired by Bekhterev's research on memory in protozoa. 
Of special significance for the development of comparative psychology in Russia are the investigations of Nadezhda Ladygina-Kots (1889-1963). Ladygina-Kots and her husband as well as colleague for life Alexander Kots were infatuated with ideas of educating people and popularizing science. Thus, an idea originated to which Alexander Kots and his wife devoted the most of their lives: the Darwin Museum, which the Kotses started at their own expense, and still exists in Moscow. ${ }^{2}$ In 1913, the Kotses presented the Museum to the Moscow High Female Courses, but did not cut ties with the museum completely, deciding to take up several rooms of the Darwin Museum to live in. They accepted the Revolution of 1917 primarily as a lucky opportunity to enlighten people, to introduce the progress of science, and Darwinism in particular, to the public. For twenty years, Ladygina-Kots worked as a guide in the Museum.

In the years before the Russian Revolution of 1917, Nadezhda Ladygina-Kots was studying behavior of anthropoid apes, macaques and chimpanzees [7]. The couple bought a young chimpanzee Iony and kept it at their own home. Nadezhda investigated emotional displays and cognitive abilities of the animal. For three years, day after day, permanent contact between the zoologists and their foster-child - chimpanzee Iony took place, unprecedented in the history of science. The materials from this research constituted the Master's thesis of Ladygina-Kots "A new method of investigating chimpanzee cognitive abilities." Nadezhda was invited to work in the Institute of Psychology (Moscow University) at the department of experimental psychology. In 1923, the first significant book by Nadezhda Nikolaevna was published - "Chimpanzee's Cognitive Abilities Research". Thanks to the opportunity to observe chimpanzee Iony, she was the first in the world to describe in detail the behavior of an infant chimpanzee - how it played as well as investigative and constructive activities. Investigating chimpanzee perception and capacity for learning was of special importance. Iony demonstrated the capacities for so-called manual thinking, generalization of information on stimuli and discovering stimuli's similarity. Much later, similar investigations on the development of infant apes, "adopted" by humans, were carried out by V. \& L. Kellog [8] and K. \& K. Hayes [9].

Ladygina-Kots knew the research of her Western colleagues well and maintained extensive correspondence with them. She discussed and debated the results of Kohler, and criticized his idea of "insight" as later Pavlov did, and much earlier than Pavlov, she presented evidence of a non-random character of animal's cuts and tries. She showed they are regular and lead to obtaining experience, useful for further action. While studying the cognitive abilities of Iony, Ladygina-Kots developed and introduced into experimental practice a new research technique known as "matching to sample." Since then psychologists and physiologists investigating various aspects of animal behavior have extensively used this method [7].

In 1925, Ladygina-Kots gave birth to her son. From the first hour of his life, until he was 7 years old, the mother made careful observations of his mental development. After careful analysis of diaries and photographs, she carried out a detailed comparison of natural behavior of the infant chimpanzee and a child of the same age (from 1 to 4 years old). The monograph "Infant Chimpanzee and Human Child: A Comparative Study of Ape Emotions and Intelligence" was translated into European languages and brought Ladygina-Kots international recognition. The main conclusions of the author were: there is

\footnotetext{
${ }^{2}$ Web-site "www. darwin.ru".
} 
a certain resemblance between many forms of chimpanzee's and human being's behavior, between their expressive patterns, instincts, sounds, imitations, motion and games, but nevertheless, there are essential distinctions in emotions' qualities and in the games (e.g., nothing like human constructive games was observed in apes). Therefore, the conclusion of Ladygina-Kots was that the main psychic processes of the human being differ qualitatively from those of the chimpanzee.

Ladygina-Kots studied perception, emotions, memory and mental abilities through the prism of evolution. She analyzed the development of the mind from protozoa to the human being. As a Darwinist, Ladygina-Kots emphasized the evolutionary nature of human cognition and emotion like contemporary Western evolutionary psychologists ${ }^{3}$ do. However, her views were substantially different. She stressed the dialectics of human nature and highlighted, alongside with similarities, fundamental differences between animals and human beings. She always insisted that an ape is in no way human, "absolutely not human, rather than not absolutely human", as she used to say. This opposition seems to make her works particularly interesting for contemporary specialists. Oxford University Press issued a book in 2002: "Infant Chimpanzee and Human Child: A Classic 1935 Comparative Study of Ape Emotions and Intelligence." This is a paperback book of the classic work by Ladygina-Kots. The fact that it has been returned to the international scientific community after an absence for many years is the evidence of the significance of Ladygina-Kots's work for international science.

\section{New scientific centers for comparative psychology in the USSR. Investigations of Ivan Pavlov}

After the Revolution of 1917, research in comparative psychology in the USSR was actively developing. In 1927, the Sukhumi Apery was founded, which became an important research center. Ivan Pavlov supported the organization of the Apery in Sukhumi. When requested by the Academy of Sciences regarding the feasibility of the apery, Pavlov responded that the apery undoubtedly presented great interest for biology. Pavlov's interest in investigations of apes was explicit. There is a common belief that Pavlov mainly did experimental research on dogs, but he had a keen interest in researching psychic functions and the behavior of apes as well. He believed that these investigations were a key to understanding the evolutionary roots of the human mind, as well as qualitative distinctions of the latter, apes being the closest evolutionary relatives to humans.

The comprehensive biography of Ivan Pavlov, written by Daniel Todes [10], describes in detail Pavlov's experimental work with chimpanzees, which lasted from 1933 until Pavlov passed away in 1936. It is worth mentioning that Todes' book brings to the light important aspects of Pavlov's investigations, often ignored by Russian psychologists who still tend to perceive Pavlov as only a physiologist, such as Pavlov's keen interest in objective

\footnotetext{
${ }^{3}$ Evolutionary psychology formed in the international discourse in the 1980-1990s, when, based on the discovery by geneticists of the so-called group selection, sociobiology appeared, which was the impetus for the emergence of evolutionary psychology. Evolutionary psychology uses a specific theory and methodology, which it applies to the traditional field of research of comparative psychology - the emergence and formation in the evolution of the human mind. In this regard, we assume that evolutionary psychology can be considered as one of the approaches in comparative psychology. As evolutionary psychology develops, the diversity of approaches increase, thus, the contemporary discourse clearly shows a tendency to use the concepts of comparative and evolutionary psychology as synonyms.
} 
research and scientific understanding of higher mental processes and his contribution to psychological science.

In 1933 a Center for Anthropoid Research of the Russian Academy of Sciences was opened in the village of Koltushi near Leningrad (St. Petersburg), where Ivan Pavlov was overseeing research. Two young chimpanzees, Rosa and Rafael, were brought to Koltushi from France, by Pavlov's Ph.D. student Pjotr Denisov. Experimental research of the apes' behavior became Denisov's Ph.D. project, supervised by Pavlov. Denisov's experiments were based largely on those Kohler described in his "Mentality of Apes" [11] and "Gestalt Psychology" [12], which Pavlov was often polemicizing against, as Pavlov wanted to examine Kohler's evidence for ascribing "insight" to chimps and denying that their behavior could be explained in associationist terms. In the "Mentality of Apes," Kohler emphasized the inability of associationists to explain such learning. He criticized behaviorism and he expressed doubts about the "law of contiguity" that underlay Pavlov's research and dismissed Pavlov's schema as a mere rephrasing of associationist doctrine.

The first experiments at Koltushi followed Kohler's basic design. From his observations of Roza and Rafael, Pavlov completely rejected Kohler's claim that anthropoids learned not through the accumulation of associations, but rather through an insight into the general perceptual field. In experimental trials, Pavlov insisted that his chimps' learning process began with what Americans termed "trial and error." By January 1935, Pavlov and Denisov had tested and re-interpreted Kohler's observations. In early 1935, Pavlov gathered his thoughts in a manuscript titled "The Intellect of Anthropoid Apes." This essay that was never completed reflected his confidence about some issues and his difficulties with others. He repeated his comments about Kohler's fallacies: about the essential continuity between the learning process in dogs, chimps, and humans; about the superior intelligence of the chimp due to the use of its four hands to develop "extraordinarily more complex mechanical interrelations" with its environment; and about his own ability to explain the chimp's problem-solving process in terms of associations. There was no need for Kohler's "insight." In this "visible and indubitable act of thinking, recognized as such by psychologists, there is nothing other than simple and complex associations" [10, p. 662].

The experimental work of Pavlov and Denisov in Koltushi was even filmed. The film "Rosa and Rafael" was very popular and widely known in Russia. ${ }^{4}$ But after the year 1937 the name of Denisov was withdrawn from the film and from every other venue because Denisov was accused, as many others, in the course of the repressions in the midthirties. In fact, the KGB arrested him three times, but the first two times Ivan Pavlov saved him by his personal intercession. After Pavlov's death, Denisov was executed in 1937. Denisov was fully rehabilitated in 1957, but in the film and in other Soviet sources on chimpanzee investigations, he is still hidden under the label of "the experimenter" [13].

\section{Comparative Psychology in Soviet Universities. Investigations} of Kurt Fabri and Nina Tikh

Well-equipped laboratories of Comparative psychology were functioning in Moscow State University and in Leningrad State University.

${ }^{4}$ Joint production of the Institute of Physiology, Academy of Sciences of the USSR and the film studio "Lenfilm" (director V. N. Nikolai, scientific consultant P. K. Denisov, assistant director G. A. Brusse. 1935). 
Kurt Fabri (1923-1990), a pupil of Ladygina-Kots, chaired the unit of comparative psychology in Moscow State University. Kurt Fabri was born in Vienna and in 1932, the family moved to the Soviet Union where his father, one of the founders of the Communist Party of Austria, was granted political asylum. In 1949, Fabri graduated from the faculty of biology of Moscow State University. His Master's thesis, dedicated to complex forms of monkeys' behavior, received a mark of "excellent with distinction." From his student years, Fabri closely cooperated with the Darwin Museum and with the Kots' family. LadyginaKots became his supervisor and since then, she supported his work.

Fabri's life in science was not easy. The 1950s were a difficult time for comparative psychology because of the pressure of "ideological" demands to substitute psychological methods and theories in investigations of animal behavior with those from physiology. An academic carrier was not possible in comparative psychology at that time, and Kurt had to work at the Library of Foreign Literature, on the radio and television, and even did some work for an animal circus (the Durov's Corner). It was not until 1964 that he obtained his first academic position of a junior researcher at the Institute of Biophysics. Here he studied imprinting in birds and obtained some new data on the nature of this phenomenon. It was at the institute that his first students appeared - those from the department of Vertebrate Zoology in Moscow State University.

Fabri received his $\mathrm{PhD}$ (Candidate of Biological Sciences) relatively late - in 1967, when he had already more than 30 major publications. The next period of the life and work of Fabri was associated with the Research Institute of Pre-school Education of the USSR Pedagogical Academy, where he organized a group of colleagues who engaged in studies of "child-animal" relations under his leadership. The results of the scientific activities of the group were presented in several $\mathrm{PhD}$ theses of the group members. From 1966 Fabri lectured on ethology and animal psychology at the Biological Faculty of Moscow State University and at the Faculty of Psychology, when it was opened. At this time he became acquainted with the works of Lorenz and Tinbergen and was very enthusiastic about their ideas. He sought to introduce them to Russian biologists and psychologists, and it was thanks to the efforts of Kurt that Soviet readers knew the works of Lorenz and Tinbergen. Fabri was the scientific editor and the author of the foreword of the first Soviet editions of the books by Lorenz and Tinbergen.

In 1971, Fabri moved to Moscow State University, to the Faculty of Psychology. Here he worked first as a senior lecturer, then as an assistant professor, and from 1983 as a Professor of the Department of General Psychology. All future psychologists attended his course "Fundamentals of animal psychology," and many attended his special course on ethology as well. The main areas of his research were the ontogenesis of animal behavior, the evolution of mind, mental activities of apes, and ethological and bio-psychological aspects of anthropogenesis. He authored over 200 scientific publications.

Fabri strongly supported new domains of applied animal psychology. One of his last works was a tutorial on ichtio - psychology, specially prepared for one of the leading universities of the country, engaged in the training of specialists in the field of industrial fishing, the Kaliningrad Technical Institute of Fishing Industry and Economy.

For his monograph "Fundamentals of animal psychology" [14], he was awarded the degree of Doctor of Psychological Science ${ }^{5}$. This book, republished in 1993 and 1999, is

${ }^{5}$ In Russia we have a two-level PhD system: Candidate of science, which is acknowledged as $\mathrm{PhD}$, and Doctor of Science, Habilitat Doctor, Professor. 
in many respects correlated with the "Problems of Psychic Development" [15] by Alexey Leontiev (1903-1979) and was used as one of the main textbooks in the process of psychological education at MSU.

Nina Tikh (1905-1983), who chaired the unit of Comparative Psychology in Leningrad (St. Petersburg) State University, graduated from Herzen University in Leningrad, and then in 1935 she received her $\mathrm{PhD}$ from the Moscow Psychological Institute under the supervision of Vladimir Borowski.

In 1936, she began her work in the Sukhumi Apery, which lasted for 16 years. She studied the gregarious life of primates as part of the problem of anthropogenesis. Her second doctoral thesis was entitled "The gregarious life of apes and their means of communication in the light of the problem of anthropogenesis."

From 1936 to 1952 she worked in the Sukhumi Apery with another prominent zoopsychologist Nickolai Voytonis (1887-1946). In 1952, she was invited to the Leningrad State University as professor of the department of general psychology. Here her investigations were related to two areas: observation of the monkeys in the Leningrad Zoo and the study of the behavior and mind of children from an early age, their motor skills and language development. In 1966 her book "Early ontogeny of behavior of primates" [16] was published, based on a comparative analysis of humans and apes.

Tikh was the first among Russian comparative psychologists who focused on social interactions and the community structure of animals. The famous Ladygina-Kots and her pupils and followers, as well as followers of Pavlov in his studies of behavior and mental functions of apes, focused on cognitive and manipulative functions, on the orientingresearch activities and problem solving of their subjects.

In 1970 her main work "Pre-history of the Society" [17] was published, which addressed the issue of the development of the gregarious life of primates in the context of the problems of anthropogenesis and the emergence of human society. She discussed in detail apes' means of communication, psychomotor activities and sounds. A theoretical reconstruction was undertaken of the pre-hominid community.

The book by Nina Tich "Prehistory of society" is based on years of the author's work in the Sukhumi Apery where she conducted observations and experiments on apes and monkeys: chimpanzees, baboons, etc. The book contains detailed diary records: descriptions of the behavior of monkeys in conditions close to natural and synthesis and generalizations of empirical data. In particular, the book provides a detailed "Dictionary" of sounds made by monkeys of different species, with appropriate explanations concerning the situations in which these sounds are produced and their asserted meaning.

A special feature of the book is that, along with empirical observations, the book contains extensive theoretical discourse. The author discusses here investigations of wellknown Western scholars of her time, such as Bingham, Crawford, Yerkes, Zuckerman, etc. She disputes their theoretical positions, vindicating propositions that are different from those that dominated in Western science of that time.

The book contains extensive criticism of the work of British zoologist Zuckerman (1904-1993), who was considered in 1930-1960s to be one of the leading specialists in the field of primatology in Europe. Primarily, Tikh pointed to poor management of the scientific experiments of Zuckerman at the London Zoo, grounding her criticism on the fact that his conclusions were based on very short-term observations of primates' life. 
However, her main critical comments were aimed at the general theoretical conclusions of Zuckerman. She wrote, "Zuckerman presents us a pretty grim picture of life in the apes' community. "Rampant egoism," which is based primarily on the sexual drive, causing continuous "sexual fights"; massive mortality of females and cubs, complete indifference of the community members to the fate of one another; ... the complete absence of any "friendly" relations whatever between individuals - that is how Zuckerman characterizes the community life of our closest relatives among wildlife" [17, p. 44].

Dismissing this picture, Tikh provided detailed and scrupulous observations of "social" interactions in the community, revealing altruistic behavior in many aspects, certain mutual aid and support in the community as a whole, as well as existence of "personal" relationships and preferences. Of special interest for her was the care for other's cubs she observed, displayed not only by females, but also by males, and primarily by alpha males. She wrote, "....manifestations of care for the young, not caused by any observable external factors, reveal the drive to communicate with the cub in apes, and are a most specific feature distinguishing apes from other species. If a cub cries from injury or being lost, abandoned by his mother, members of the group immediately respond to him from a distance, approach him, guiding his actions and making "soothing" low-pitched communicative sounds" [17, p. 133].

Tikh describes the keen attention and interest with which members of the community greet the appearance of a newborn baby in their midst. Adults, teenagers, old females, the alfa male, surround the mother by a tight circle. All watch the cub closely and attempt to enter into contact with him, making specific sounds or trying to touch him. However, the mother guards the young jealously, clutching him tightly. Tikh marks that the emergence of a cub has a positive effect on the status of a female: she obtains more access to food, the male provides her more protection than before, and she has more possibilities to choose contacts with members of the group. The major access to the cub is by the alfa male and females, which are in "friendly" relations with the mother. They sometimes can touch the baby with their hand or snout, making appropriate sounds. These manifestations of active general attention continue for a few days and gradually diminish, but do not disappear entirely before the end of the infancy of the baby. A thoracic cub attracts the attention and affection of all members of the group. Mature females display particularly pronounced attention. Passing someone else's baby, each female usually clicks her tongue and produces a special sound, "mlah-mlah-mlah."

Based on her observations of life in apes' communities, Tikh criticized the theory of male dominance in human history, highlighting the contribution of females in the prehistory of humanity. Tikh pointed to the technical innovations that could be implemented by females, thus destroying one of the most common stereotypes, depicting women as outsiders from historical process, who are unable to support progress. She assumed that objects like scrapers, needles and other small tools are the product of females' activities. Thus, human culture was created and developed by both sexes, and at the beginning of human history females, most likely, contributed to that even more than males. 


\section{The importance of Comparative Psychology in Russian Psychological Tradition}

Russian comparative psychology focused on ontological issues and was considered very important in the context of Soviet psychological science. Grounding on Marxist theory, Soviet psychologists aimed to explicate, on the one hand, the materialistic origin of the mind, and the naturalness of its occurrence in the process of evolution; and on the other hand, the crucial difference between humans, versatile and subject to the influence of social factors, and other living beings, exposed to the absolute power of the universal laws of Nature. Soviet general psychology was based on theoretical models of evolution of mind and behavior, developed in comparative psychology.

It is not well known in the international professional community that Lev Vygotsky placed a special emphasis on evolutionary aspects of psychic development. This is most fully presented in his works: "Essays on the history of behavior (ape, primitive, child)" (in co. with A.Luria) [18] and the Preface to the Russian edition of the book by W. Kohler "Research on Intelligence of Apes" [19].

One of the few examples of books by Soviet psychologists, known to Western colleagues, is the "Problems of the Development of Mind" [20], by Alexei N.Leontiev - an abridged translation of his book, earlier published in Russian under the name "Problems of Psychic Development." This book, which is rightly supposed to be the most important for understanding Leontiev's variant of the Activity Theory, largely represents data from comparative psychology theory and research and is correlated with Fabri's "Basics of Animal psychology" [14]. Here, Leontiev presented a theoretical model of the evolutionary development of mind, well illustrated with examples from experiments in comparative psychology.

Analyzing the works of Soviet comparative psychologists, we constantly observe acute discussions and controversies with Western colleagues. Evidently, this was in part, a forced action due to political reasons, because from the very beginning Soviet science was meant to be alternative to Western "bourgeois" science. However, it was not only political maneuvering. There were serious distinctions in the way the problem of evolutionary development of mind was treated $[21,22]$. A primary distinction is that Soviet comparative psychology, in contrast to Western science, focused much more on the problem of human phylogenesis. In fact, all theoretical generalizations of experimental research of Soviet comparative psychologists were in their way addressing the central issue: the border between the human and animal mind, essential for the Socio-Cultural Theory.

According to this tradition, which goes back to the works of Sechenov and Pavlov, "Biological" and "cultural" factors are viewed as non-derivable from one another and potentially annul the influence of each. The overlapping between contradictory biological laws and cultural regulations is viewed as a basis for the flexibility of human personality development, individual personality uniqueness and freedom of will. Focusing on human onto- and phylogenesis, Russian comparative psychology was based on evolutionary theory - it was an evolutionary psychology in fact - but the understanding and interpretation of evolutionary theory were very different from contemporary "Evolutionary psychology" in Western science. ${ }^{6}$ Russian psychologists further developed the position that human evolution continues, and the main factors determining the process for humans are cultural. Culture

${ }^{6}$ It's interesting to mention that D. Todes points to an initially specific understanding of Darwin's evolutionary theory by the Russian academy (Todes, 1989). 
in humans was considered as primarily the ability to change under the influence of social surroundings, the speed and extent of changes making humans unique among other animals. This entailed a focus on ruptures and discontinuities in evolution, primarily on the principal differences between human and animal $[22,23]$. The unity of nature and culture in humans was considered as not only based on similarities, but also on contradictions, and investigations mainly focused on these contradictions, as they were supposed to account for the dialectics of change and development of human species, both cultural and biological.

\section{Conclusion}

Soviet comparative psychology was a sustainably developing school, well-grounded in neurophysiology and physiology, and closely connected with general psychology. Its development was interrupted in the 1990s because when "perestroika" began, governmental support of science and education was seized [21,22]. Research in comparative psychology, costly and not profitable, was ceased. Comparative psychology, once a mandatory component of psychological education, disappeared from the curricula in postSoviet years. The courses started to reappear in the 2010s, but they are now mainly taught by zoologists as animal behavior stories, referring more to Western sources than to Russian authors. The theoretical grounds and research of Soviet comparative psychologists are hardly mentioned: the path they were taking has been abandoned. The laboratory for comparative psychology at MSU now includes two researchers, and in St. Petersburg State University there is no special unit at all.

Does the work, which Russian psychologists were doing for decades, deserve its place in the history of psychological science? I believe the answer is "Yes". Their life and work should be remembered, if just for the sake of the history of our science, as a meaningful episode in the life of a professional community. However, I believe this is not the only reason to shed light on this scientific school today.

The idea of ruptures in evolutionary processes and of continuing human evolution was incorporated into the basis of Russian Cultural-Historical Theory in general. Russian Cultural-Historical Theory was created in the 1920s in post-revolutionary Russia where a great experiment, aimed to test Marxist theory in practice was carried out. This situation accounted for the radical and even arrogant nature of the new Marxist psychology. In contrast to static concepts and implicit theories of universal human nature, dominant in Western psychology, Russian Activity Theory, driven by the idea of managing human evolution in order to prove the "bolshevik understanding" of Marxist theory dominant in Soviet discourses after 1920s, was based on the understanding of the human as an infinitely changing creature.

A specific feature of Russian comparative psychology is the importance attached to the dialectics of human nature, and thus to the depth and scope of cultural and biological diversity of the human species. This idea fits the reality of the contemporary transforming multicultural world and might contribute to current discussions not only in comparative psychology, but also of the philosophical basis for psychological science in general [23].

\section{References}

1. Sechenov I. M. Psychological Studies. St. Petersburg, Sushchinskii Publ., 1873. (In Russian)

2. Sechenov I. M. Who Must Investigate the Problems of Psychology, and How. St. Petersburg, Sushchinskii Publ., 1873. (In Russian) 
3. Sechenov I. M. Elements of Thought. Vestnik Evropy, 1878, no. 4. (In Russian)

4. Bekhterev V.M. The Objective Psychology. Moscow, Nauka Publ., 1907. (In Russian)

5. Vagner V. Biological foundations of comparative psychology. In 2 volumes. St. Petersburg, Volf Publ., 1910-1913. (In Russian)

6. Vagner V. Psychic genesis and development. In 9 volumes. St. Petersburg, Volf Publ., from 1924 to 1929. (In Russian)

7. Ladygina-Kots N. Infant Chimpanzee and Human Child: A Classic Comparative Study of Ape Emotions and Intelligence. Oxford University Press, 2002. (In Russian)

8. Kellog W.N., Kellog L. A. The ape and the child. New York, McGraw-Hill, 1933.

9. Hayes K., Hayes C. The intellectual development of home-raised chimpanzee. Proc. Am. Phil. Soc., vol. 95, 1951, pp. 105-109.

10. Todes D. Ivan Pavlov: A Russian Life in Science. Oxford University Press, 2014.

11. Kohler W. The Mentality of Apes. New York, Harcourt Brace, 1925.

12. Kohler W. Geshtalt Psychology. H. Liveright, Psychology, 1929.

13. Firsov A. Annals of the History of the Koltushi Apery. The oppressed Science, St. Petersburg, Nauka Publ., 1994, pp. 200-208. (In Russian)

14. Fabri K. Basics of animal psychology. Moscow, MSU Publ., 1976. (In Russian)

15. Leontyev A. N. Problems of Psychic Development. Moscow, Mysl' Publ., 1965. (In Russian)

16. Tikh N. Early ontogeny of behavior of primates: comparative psychological research. Leningrad, LGU Publ., 1966. (In Russian)

17. Tikh N. Pre-history of the Society. Leningrad, LGU Publ., 1970. (In Russian)

18. Vygotsky L. S., Luria A. Essays on the history of behavior (ape, primitive, child). Moscow, Leningrad, GIZ Publ., 1930. (In Russian)

19. Kohler W. Research and Theory on Human Development. The Journal of Genetic Psychology Research and Theory on Human Development, 1991, vol. 152, pp. 470-486. Available at: https://doi.org/10.108 0/00221325.1991.9914708. (accessed: 15.10.2019). (In Russian)

20. Leontiev A.N. Problems of the development of mind. Moscow, Progress Publ., 1981. (In Russian)

21. Mironenko I. A. The past, the present and the future of Russian comparative psychology. Metodologia $i$ istoria psikhologii, 2009, vol. 4 (2), pp. 45-59. (In Russian)

22. Mironenko I. A. Russian Psychology in the Context of the International Science (in Russian). St. Petersburg, Nestor-Istoriia Publ., 2015. (In Russian)

23. Mironenko I. A, Zhuravlev A. L. The Biosocial Problem in the Context of Global Psychological Science: Concerning the "Universal" Human Psychology. Psikhologicheskii Zhurnal, 2019, vol. 40 (6), pp. 112123. (In Russian)

24. Ladygina-Kots N. Research on Chimpanzees' Cognitive Abilities. Moscow, Gosizdat Publ., 1923. (In Russian)

25. Ladygina-Kots N. Infant Chimpanzee and Human Child: their instincts, emotions, play, habits and expressive movements. Moscow, Darwin Museum Publ., 1935. (In Russian)

26. Ladygina-Kots N. Constructive and Instrumental Activity of Anthropoid Apes. Moscow, Academy of Sciences Publ., 1959. (In Russian)

27. Novoselova S. L. Nadezhda Nikolaevna Ladygina-Kots - the pride of Russian science. Personality Development, 2001, no. 3-4, pp. 76-107. (In Russian)

28. Todes D. Darwin without Malthus: The Struggle for Existence in Russian Evolutionary Thought. Oxford University Press, 1989.

29. Vygotsky L. S. Preface. W. Kohler. Research on Intelligence of Apes. Moscow, Acad. Com. Ped. Publ., 1930, pp. 1-29. (In Russian)

30. Vygotsky L.S. Psychotechnics and pedology. Psihotehnika i psihofiziologiâ truda, 1931, vol. 2-3, pp. 173-184. (In Russian)

Received: October 31, 2019

Accepted: December 12, 2019

Authors'information:

Irina A. Mironenko - Dr. Sci. in Psychology; mironenko.irina1@gmail.com

Veronika A. Rafikova - Postgraduate Student in Psychology; veronikarafikova1996@gmail.com 


\title{
Об истории сравнительной психологии в России
}

\author{
Мироненко И. А., Рафикова В.А.
}

Санкт-Петербургский государственный университет,

Российская Федерация, 199034, Санкт-Петербург, Университетская наб., 7-9

Для цитирования: Мироненко И.А., Рафикова В.А. Об истории сравнительной психологии в России // Вестник Санкт-Петербургского университета. Психология. 2020. Т. 10. Вып. 1. С. 6172. https://doi.org/10.21638/spbu16.2020.105

Российская психология в советский период развивалась в относительной изоляции от мировой науки. Многие исследования советских психологов до сих пор остаются неизвестными международному научному сообществу, особенно работы, выполненные после 1930-х годов. В первые десятилетия советской власти еще работали ученые, которые получили образование в досоветский период, владели иностранными языками, обучались и стажировались в Европе, особенно часто в Германии. Новые поколения, которые выросли при советской власти, в соответствии с политикой в эпоху «железного занавеса» были лишены возможности непосредственно участвовать в международном дискурсе. Развитие российской психологии в этих условиях привело к формированию специфической концептуальной системы, которая по-прежнему является серьезным препятствием для интеграции достижений российской науки в мировой контекст, поскольку труды требуют не только языкового перевода, но и герменевтики. В то же время в российской советской психологии существуют оригинальные разработки, в основном в области фундаментальных исследований, связанных с биологическими науками, которые и сегодня могут внести вклад в интернациональную науку. К таким областям относится российская сравнительная психология. В статье раскрыта специфика подхода, на котором основывались исследования российских ученых, показано, что особенностью российской сравнительной психологии является диалектический подход к человеческой природе, который соответствует реальности современного трансформирующегося мультикультурного мира. Разработки советских сравнительных психологов могут внести вклад в современные дискуссии о сравнительной психологии и о философских основаниях психологической науки в целом. В статье освещается история развития сравнительной психологии в России, приводятся факты о жизни и деятельности ряда выдающихся представителей советской школы в области сравнительной психологии (Н.Н. Ладыгина-Коц, К.Фабри, Н.А. Тих), представлены исследования в этой области, выполненные в лаборатории И. П. Павлова.

Ключевые слова: история сравнительной психологии, развитие сравнительной психологии, эволюционная психология, антропогенез, филогенез человека, онтогенез человека, теория деятельности, психология в России.

Статья поступила в редакцию 31 октября 2019 г.; рекомендована в печать 12 декабря 2019 г.

Контактная информация:

Мироненко Ирина Анатольевна - д-р психол. наук; mironenko.irina1@gmail.com

Рафикова Вероника Айдаровна - аспирант; veronikarafikova1996@gmail.com 